\title{
Competitiveness of management-intensive grazing dairies in the mid-Atlantic region from 1995 to 2009
}

\author{
J. C. Hanson, ${ }^{1}$ D. M. Johnson, E. Lichtenberg, and K. Minegishi \\ Department of Agricultural and Resource Economics, University of Maryland, College Park 20742-5535
}

\begin{abstract}
This paper used farm income tax returns (Schedule F) data from 62 dairy farmers who milked 200 cows or fewer in western and central Maryland and southwestern Pennsylvania (hereafter, the mid-Atlantic region) to assess the relative financial performance of management-intensive grazing (MIG) and confinement dairy operations over the 15-yr period from 1995 through 2009. Data were not available from all farmers in all years; on average, the sample analyzed contained 11 MIG farms and 26 confinement farms. Managementintensive grazing operators were more profitable on a per hundredweight, per cow, and per acre basis, and no less profitable on a whole-farm basis. Even though the confinement operators had higher gross income than MIG operators, their expenses exceeded those of MIG operators. Profits of MIG operations were less variable as well, so that MIG operators faced less income risk. Increased reliance on grazing has other benefits as well. Grazing seems to be a much healthier practice for dairy cows. Veterinary, breeding, and medicine costs per cow are much less for cows that are pastured than those raised in confinement systems. Because they are healthier, cows that are grazed can be milked longer (or culled less frequently). As a result, MIG operators have a larger number of higher quality animals for sale (e.g., bred heifers). Management-intensive operations are also less labor intensive. Reductions in crop production and in the time cows spend in the barn led to significant reductions in field work and cleaning operations in the barn. Costs of hired labor were thus substantially lower in MIG operations than in confinement operations. Land requirements likely impose the principal limitation on the size of intensive grazing operations. In the mid-Atlantic, for instance, grazing operations need 1.5 to 2.0 acres of pasture for every dairy cow/ calf equivalent to provide sufficient grass to support a dairy operation. Pasture land for MIG operators must be contiguous to the milking parlor and located no
\end{abstract}

Received December 6, 2011.

Accepted November 15, 2012.

${ }^{1}$ Corresponding author: jhanson@arec.umd.edu farther than a cow can walk to and from twice a day. That requirement likely limits the maximum size of an intensive grazing operation, especially in areas where land prices and rents are high, as they are in much of the mid-Atlantic.

Key words: management-intensive grazing, profitability, risk analysis, mid-Atlantic region

\section{INTRODUCTION}

The US dairy industry has been changing rapidly, consolidating into fewer, larger operations. Between 2000 and 2006, for instance, the number of dairy operations in the United States fell by $26 \%$. That entire decline occurred in operations with $<500$ cows; the number of operations with 1,000 to 1,999 cows increased by about $25 \%$, whereas the number of operations with $\geq 2,000$ cows doubled. Data from the US Department of Agriculture Agricultural Resource Management Survey indicate that large farms exhibit significant economies of scale: larger herds make it possible to spread fixed costs of housing facilities, milking equipment, and machinery over a larger volume of output, thus lowering average production costs (MacDonald et al., 2007). Demand for milk has not risen as rapidly as productivity, leading to downward pressure on prices. As a result, smaller dairies that have been a mainstay of traditional rural landscapes in many parts of the United States have found it difficult to compete (Mosheim and Lovell, 2009; Nehring et al., 2009; Winsten et al., 2010).

Those competitive pressures have led some dairy operators to experiment with land-intensive production systems as an alternative to traditional capitalintensive production systems. Studies using data from short-term experiments and single-year farm records indicate that management-intensive grazing (MIG) systems can be more profitable than confinement systems because lower operating costs more than offset the lesser milk production. Controlled experiments (White et al., 2002; Fontaneli et al., 2005) and budgeting studies (Hanson et al., 1998; Dartt et al., 1999; Gloy et al., 2002; Tozer et al., 2003; Kriegl, 2005; Taylor and Foltz, 2006) have shown MIG operations to be at least as profitable as traditional confinement operations - in 
total net farm income as well as per cow net income. Multivariate regression analyses have reached similar conclusions (Gloy et al., 2002; Gillespie et al., 2009).

Intensive grazing operations may also have a competitive advantage in managing risk. Milk prices have become more variable over the past 2 decades, subjecting dairy operators to greater risk. Lower operating and capital costs tend to make MIG operations less vulnerable to price fluctuations (Winsten et al., 2000) as well as offering lower barriers to entry for young farmers (Taylor and Foltz, 2006). Greater reliance on grazing has been shown to improve animal health in several respects as well (see Winsten et al., 2010 for a brief survey). And MIG operations are thought to have superior environmental performance in terms of reduced sediment erosion (Digiacomo et al., 2001), lower phosphorus runoff (Winsten and Stokes, 2004; Bishop et al., 2005), increased carbon sequestration (Guo and Gifford, 2002), and provision of wildlife habitat (Renfrew and Ribic, 2001).

This paper used farm income tax returns (Schedule F) data from 62 dairy farmers in western and central Maryland and southwestern Pennsylvania (hereafter, the mid-Atlantic region) to assess the relative financial performance of MIG and conventional dairy operations over the 15-yr period from 1995 through 2009. We compared income and expenses on a per farm, per hundredweight of milk, and per cow basis to assess performance in terms of household income and productivity. We also compared income and expenses on a per acre basis to assess the potential effects of land constraints. The data allow the use of methods that control for year-to-year fluctuations in weather, prices, and similar factors, enabling more robust comparisons of financial performance than is possible with single-year data. Additionally, data spanning multiple years allow comparisons of the riskiness of income on a per farm basis to assess the vulnerability of household income to fluctuations in milk prices and input costs. Those multiple comparisons allow evaluation of the economic viability of MIG systems compared with similarly sized confinement dairy systems.

\section{MATERIALS AND METHODS}

\section{Data}

The data in this study come from the Maryland Dairy Farm Business Summary, a program of the University of Maryland Extension (Western Maryland Research and Education Center, Keedysville) that helps farmers analyze their operational strengths and weaknesses. Since 1995, the program has collected data on income, expense, and profit from 1040 Schedule F forms from
62 participating farmers. Not all 62 farms participated each year. Pooling all farm-level observations across the years 1995 to 2009, the data set contained 556 observations in total. All dollar-denominated variables were adjusted for inflation with the Consumer Price Index for the Northeast region.

Although the sample used in this study was selfselected, consisting of farmers who voluntarily sought assistance from University of Maryland Extension, it was largely representative of dairy operations in the state. Comparisons with data from the Census of Agriculture (Table 1) for the years overlapping with the sample used here $(1997,2002,2007)$ indicated no difference between operations in the sample used in this study and the state population of dairy operations in terms of the distribution of herd sizes in 1997 and 2002 or in terms of the distributions of net profit or of revenues from sales of milk, cattle, and crops in 2002. The sample used here did differ from the state population in having fewer operations with $<50$ cows in 2007, fewer operations with sales $<\$ 100,000$ in 1997 and 2007, fewer money-losing operations in 2007, and no operations with >500 acres in 1997, 2002, and 2007.

Two different types of dairy farms were analyzed: conventional confinement operations and MIG operations. Management-intensive grazing operations are characterized by a short period of intensive grazing by many animals on a small paddock and then a rotation to another paddock, usually after each milking or daily. Animals do not return to the first paddock until the grass has fully recovered, usually in 3 to $6 \mathrm{wk}$, depending on time of the season, weather conditions, and rotational system. As a result of a greater reliance on pasture as feed, MIG operators typically grow less field crops than traditional confinement operators. In this study, MIG operations were defined as farms whose herd rations included at least 30\% DM from pasture for a minimum of $4 \mathrm{mo}$, a criterion that is also used for certifying milk as organic. Management-intensive grazing operators in the study ranged from 4 to 8 mo of pasture production, with the average of $6.7 \mathrm{mo}$. The number of months that a MIG operator can utilize pasture will, of course, vary by geography and climate. All farmers in this study were located within a 125-mile radius of each other in western and central Maryland and southern Pennsylvania.

Of the 62 farmers in the sample, 43 used conventional production systems throughout the entire sample period and 14 used MIG systems throughout the entire sample period. The remaining 5 switched from conventional to MIG systems during the sample period. The average length of participation was $8 \mathrm{yr}$.

All of the farms included in this study were on the smaller end of the dairy herd size spectrum. Within that 
Table 1. Comparison of sample with all Maryland dairy farms

\begin{tabular}{|c|c|c|c|c|c|c|c|c|}
\hline Year & Source & \multicolumn{6}{|c|}{ No. of farms by herd size (no. of cows) } & Pearson $x^{2}$ \\
\hline 1997 & Census & 220 & 400 & 211 & 43 & 6 & 880 & 8.63 \\
\hline \multirow[t]{2}{*}{2002} & Census & 179 & 268 & 197 & 42 & 8 & 694 & 6.60 \\
\hline & Sample & 4 & 18 & 16 & 3 & 0 & 41 & \\
\hline \multirow[t]{2}{*}{2007} & Census & 180 & 198 & 131 & 47 & 7 & 563 & $18.45^{* * *}$ \\
\hline & & $<-50$ & -50 to -10 & -10 to 10 & 10 to 50 & $>50$ & Total & \\
\hline \multirow[t]{2}{*}{2002} & Census & 48 & 34 & 78 & 151 & 321 & 632 & 8.03 \\
\hline & Sample & 0 & 3 & 5 & 16 & 17 & 41 & \\
\hline \multirow[t]{2}{*}{2007} & Census & 27 & 39 & 57 & 111 & 331 & 565 & $9.80^{* *}$ \\
\hline & Sample & 1 & 1 & 2 & 15 & 20 & 39 & \\
\hline 1997 & Sample & 0 & 2 & 14 & 19 & 1 & 36 & \\
\hline \multirow[t]{2}{*}{2002} & Census & 49 & 128 & 251 & 188 & 82 & 698 & 7.84 \\
\hline & Sample & 0 & 3 & 20 & 12 & 6 & 41 & \\
\hline \multirow[t]{4}{*}{2007} & Census & 37 & 61 & 196 & 158 & 113 & 565 & $10.81^{* *}$ \\
\hline & Sample & 0 & 1 & 11 & 13 & 14 & 39 & \\
\hline & & \multicolumn{6}{|c|}{ No. of farms by acreage } & \\
\hline & & 1 to 69 & 70 to 139 & 140 to 219 & 220 to 499 & $500+$ & Total & \\
\hline \multirow[t]{2}{*}{1997} & Census & 34 & 107 & 224 & 379 & 145 & 889 & $33.22^{* * *}$ \\
\hline & Sample & 1 & 8 & 17 & 2 & 0 & 28 & \\
\hline \multirow[t]{2}{*}{2002} & Census & 34 & 94 & 143 & 292 & 135 & 698 & $36.80^{* * *}$ \\
\hline & Sample & 2 & 9 & 18 & 4 & 0 & 33 & \\
\hline
\end{tabular}

**, *** indicate statistically significant differences between Census and Sample at the $5 \%$ and $1 \%$ levels, respectively.

range, however, confinement operators had larger dairy operations than MIG operators, with herd sizes $20 \%$ larger on average and milk production $58 \%$ greater on average (Table 2). Confinement operators also had more land than MIG operators; not surprisingly, MIG operators had more pasture acreage and less crop acreage than conventional operators, both in total and on a per cow basis. Confinement operators produced more milk and thus generated more revenue than MIG operators. But confinement operators also incurred greater expenses.

\section{Methods}

Systematic differences in returns and expenditures between confinement and MIG dairy systems were analyzed using ANOVA with fixed effects for confinement versus MIG operation and year, with the latter used to control for systematic differences across years due to weather, market conditions, and technological trends during the survey period. Separate models were estimated for milk production, profit, each category of sales, and each category of expenditures. Each model contained fixed effects for type of operation (confinement versus MIG) and year. Formally, the model estimated for response variable $\mathrm{Y}$ on farm $\mathrm{k}$ in year $\mathrm{t}$ was $Y_{k t}=a+b I_{k t}+c_{t}+e_{k t}$, where $I_{k t}$ is a fixed effect for type of operation, $c_{t}$ a fixed effect for year, and $e_{k t}$ a random error. An alternative specification using yearspecific random effects yielded results virtually identical to those reported here. This procedure adjusted for year-to-year variations due to weather, short-run price fluctuations, and similar factors.

The productivity of MIG and confinement operations was compared per hundredweight of milk, per cow, and per acre of land. Evaluating costs and returns per unit of output is the most common method of assessing productivity. It allows an evaluation of competitiveness, because costs and profit margins can be compared with price. Putting costs and returns on a per cow basis adjusts for scale of operation according to herd size. Land may be a limiting factor in operational scale as well, especially in MIG operations whose size may be 
Table 2. Descriptive statistics for dairy farmers using management-intensive grazing versus confinement, 1995 to $2009^{1}$

\begin{tabular}{|c|c|c|c|c|}
\hline Variable & Mean & $\mathrm{SD}$ & Minimum & Maximum \\
\hline \multicolumn{5}{|l|}{ Management-intensive grazing } \\
\hline Average number of cows/year & 86 & 29 & 37 & 195 \\
\hline Farm acreage & 283 & 134 & 115 & 700 \\
\hline Pasture acreage & 152 & 60 & 53 & 280 \\
\hline Crop acreage & 132 & 108 & 0 & 600 \\
\hline Pasture acres/cow & 1.8 & - & - & - \\
\hline Crops acres/cow & 1.6 & - & - & - \\
\hline Annual milk production (cwt) & 12,320 & 5,605 & 2,670 & 42,955 \\
\hline Gross income $(\$)$ & 268,565 & 111,946 & 71,658 & 871,990 \\
\hline Total expenses $(\$)$ & 213,664 & 98,532 & 58,557 & 718,055 \\
\hline Profit $(\$)$ & 54,901 & 42,443 & $-81,653$ & 187,917 \\
\hline Number of farmers/study & 19 & - & - & - \\
\hline Average years in study/farmer & 8.6 & 4.9 & 1 & 15 \\
\hline Average farmers in study/year & 10.9 & 3.1 & 4 & 15 \\
\hline \multicolumn{5}{|l|}{ Confinement } \\
\hline Average number of cows/year & 103 & 43 & 22 & 200 \\
\hline Farm acreage & 318 & 145 & 90 & 845 \\
\hline Pasture acreage & 52 & 39 & 0 & 141 \\
\hline Crop acreage & 266 & 133 & 60 & 704 \\
\hline Pasture acres/cow & 0.5 & - & - & - \\
\hline Crop acres/cow & 2.7 & - & - & - \\
\hline Annual milk production (cwt) & 19,523 & 8,692 & 3,761 & 41,527 \\
\hline Gross income $(\$)$ & 411,630 & 194,058 & 87,364 & $1,013,933$ \\
\hline Total expenses $(\$)$ & 363,493 & 178,227 & 66,951 & 910,419 \\
\hline Profit $(\$)$ & 48,137 & 56,003 & $-196,096$ & 315,236 \\
\hline Number of farmers/study & 48 & - & - & - \\
\hline Average years in study/farmer & 8.3 & 4.6 & 2 & 15 \\
\hline Average farmers in study/year & 26.1 & 4.2 & 17 & 32 \\
\hline
\end{tabular}

${ }^{1}$ Table 2 reports simple sample averages with no adjustment for year-to-year variations in overall averages.

constrained by the need to walk cows from pasture to the milking parlor. Assessing productivity on a per acre basis adjusts for scale of operation in this dimension. Output was measured in terms of both milk production (measured in hundredweight) alone and in terms of revenue; the latter includes sales of crops and cattle as well as adjusting milk production for quality, as indicated by price. Income from conventional and MIG operations was then compared on a whole-farm basis to assess how well these 2 production systems performed in generating household farm income.

The relative riskiness of returns under confinement and MIG systems was compared by estimating the standard deviations of profit over the sample period for each conventional and MIG operation. Separate ANOVA models for the means and standard deviations of profit in conventional and MIG operations were estimated using farm-specific fixed effects, which were used to adjust for the influence of operator managerial ability, land quality, asset composition, and other unobservable factors that remain constant over time. These estimated means and standard deviations were used to compute $75 \%$ lower confidence limits of profit as a measure of risk-adjusted income (e.g., Musser et al., 1981). Any difference in these lower bounds reflects a systematic difference in income risk that is directly attributable to the nature of MIG and conventional dairy systems. The profit level attained at least $75 \%$ of the time by each system was calculated as $\mathrm{L}_{\mathrm{i}}=\mathrm{E}_{\mathrm{i}}-$ $\mathrm{KS}_{\mathrm{i}}$, where $\mathrm{E}_{\mathrm{i}}$ is average annual profit under production system $\mathrm{i}, \mathrm{S}_{\mathrm{i}}$ is the standard deviation of profit under production system $\mathrm{i}$, and $\mathrm{K}=0.577$ is calculated using a one-sided Chebyshev inequality.

As stated, the main analysis focused on 62 farms with $\leq 200$ cows. However, a full sample of all farms that participated in the Maryland Dairy Farm Business Summary would include an additional confinement dairy with an average herd size of 401 cows. Additionally, 2 of the 62 farms included in the main analysis had more than 200 cows in some years and were thus excluded from the analysis in those years. The main analysis also included 4 MIG operations that became certified organic producers and thus received a price premium for their milk during several years. To check the robustness of main results, all models were reestimated for the full sample and for the full sample excluding MIG operators in years in which they sold organic milk.

\section{RESULTS AND DISCUSSION}

\section{Productivity Comparisons}

Per Hundredweight. Confinement farmers produced more milk on an annual basis than MIG op- 
Table 3. Average annual values (per cwt of milk) between 2 types of dairy farms, management-intensive grazing (MIG) versus confinement, based on Form 1040 Schedule F, 1995 to $2009^{1}$

\begin{tabular}{|c|c|c|c|}
\hline \multirow{2}{*}{$\begin{array}{l}\text { Form } 1040 \\
\text { (Schedule F) item }\end{array}$} & \multicolumn{3}{|c|}{ Farms with $\leq 200$ cows } \\
\hline & MIG & Confinement & Difference \\
\hline Milk sales (\$/cwt) & 19.47 & 18.43 & $-1.04^{* * *}$ \\
\hline Crop sales ( $\$ / \mathrm{cwt})$ & 0.09 & 0.28 & $0.20^{* * *}$ \\
\hline Cattle sales (\$/cwt) & 1.85 & 1.10 & $-0.75^{* * *}$ \\
\hline Income, other ( $\$ /$ cwt $)$ & 1.14 & 1.21 & 0.07 \\
\hline Gross income $(\$ / \mathrm{cwt})$ & 22.55 & 21.03 & $-1.52^{* * *}$ \\
\hline Car and truck $(\$ / \mathrm{cwt})$ & 0.06 & 0.04 & -0.02 \\
\hline Chemical expenses ( $\$ / \mathrm{cwt})$ & 0.13 & 0.49 & $0.36^{* * *}$ \\
\hline Conservation expenses $(\$ / \mathrm{cwt})$ & 0.03 & 0.02 & -0.01 \\
\hline Custom hire $(\$ /$ cwt $)$ & 0.42 & 0.60 & $0.17^{* * *}$ \\
\hline Depreciation $(\$ / \mathrm{cwt})$ & 2.45 & 1.88 & $-0.57^{* * *}$ \\
\hline Purchased feed expenses (\$/cwt) & 5.78 & 5.62 & -0.16 \\
\hline Fertilizer expenses $(\$ / \mathrm{cwt})$ & 0.48 & 0.67 & $0.18^{* * *}$ \\
\hline Freight and trucking ( $\$$ cwt $)$ & 0.58 & 0.72 & $0.14^{* * *}$ \\
\hline Fuel (\$/cwt) & 0.49 & 0.47 & -0.02 \\
\hline Insurance, other than health $(\$ /$ cwt $)$ & 0.24 & 0.29 & $0.05^{*}$ \\
\hline Interest $(\$ /$ cwt $)$ & 0.89 & 0.72 & $-0.16^{* *}$ \\
\hline Labor $(\$ /$ cwt $)$ & 0.50 & 1.03 & $0.53^{* * *}$ \\
\hline Rent or lease $(\$ /$ cwt $)$ & 1.18 & 0.93 & $-0.25^{* * *}$ \\
\hline Repairs and maintenance (\$/cwt) & 1.22 & 1.45 & $0.23^{* * *}$ \\
\hline Seeds and plants $(\$ / \mathrm{cwt})$ & 0.46 & 0.43 & -0.03 \\
\hline Supplies $(\$ /$ cwt $)$ & 1.11 & 0.85 & $-0.26^{* * *}$ \\
\hline Taxes $(\$ /$ cwt $)$ & 0.17 & 0.15 & -0.02 \\
\hline Utilities $(\$ /$ cwt $)$ & 0.57 & 0.48 & $-0.09^{* * *}$ \\
\hline Veterinary, breeding, and medicine $(\$ / \mathrm{cwt})$ & 0.53 & 0.94 & $0.41^{* * *}$ \\
\hline Other expenses $(\$ / \mathrm{cwt})$ & 0.49 & 0.74 & $0.26^{* * *}$ \\
\hline Total expenses (\$/cwt) & 17.80 & 18.58 & $0.78^{* *}$ \\
\hline Net profit $(\$ /$ cwt $)$ & 4.75 & 2.45 & $-2.30^{* * *}$ \\
\hline Net profit (metric; $\$ / \mathrm{kg}$ ) & 0.105 & 0.054 & $-0.051^{* * *}$ \\
\hline
\end{tabular}

${ }^{1}$ Income and expense numbers are expressed in consumer price index (CPI)-adjusted dollars.

$*, * *, * * *$ Significant difference between MIG and confinement dairies at the 10,5 , and $1 \%$ levels, respectively.

erators. But MIG operators earned more profit per hundredweight of milk produced (Table 3). This higher profitability of MIG operators, when compared with confinement operators, stemmed primarily from lower expenses and secondarily from higher sales of cattle. Management-intensive grazing operators also received a higher price for milk.

Notable revenue and expense differences were as follows. Intensive grazing operators earned more from sales of cattle per hundredweight of milk produced. Higher cattle sales more than compensated for lower crop sales, so that MIG operators averaged higher total revenue per hundredweight of milk produced (an average price difference partially attributable to sales of organic milk, as discussed below). At the same time, MIG operators incurred lower expenses per hundredweight of milk produced than confinement operators, most notably in terms of veterinary and labor costs. The MIG operators in the sample also incurred greater depreciation costs, possibly because of the smaller denominator of milk output or because capital assets, unlike variable cost components, could not be flexibly adjusted for smaller scale operations under MIG when farmers switched from previous confinement operations.
Greater revenues and lower expenses per hundredweight of milk produced add up to higher net profits per hundredweight of milk: MIG operators earned $94 \%$ more per hundredweight of milk than confinement operators $(\$ 4.75 / \mathrm{cwt}$ vs. $\$ 2.45 / \mathrm{cwt})$. This difference in profitability was similar to that found by Gillespie et al. (2009), whose analysis of a national sample of dairy operations found that pasture-based systems averaged profit per hundredweight of milk about $29 \%$ greater than confinement systems.

Per Cow. Herd size is the standard measure of scale in dairy operations. Operations at a disadvantage in terms of cost and profit per hundredweight of milk produced may be able to compensate by expanding their scale of operation; that is, by increasing herd size. As noted above, confinement operations in our sample were larger on average than MIG operations. That greater scale of operation might make up for lower revenues, higher costs, and lower profits per hundredweight of milk produced.

Confinement operations exhibited substantially greater milk productivity than MIG operations on this basis: milk production was $31 \%$ higher on confinement operations than MIG operations (Table 4). Confinement 
Table 4. Average annual values (per cow) between 2 types of dairy farms, management-intensive grazing (MIG) versus confinement, based on Form 1040 Schedule F, 1995 to $2009^{1}$

\begin{tabular}{|c|c|c|c|}
\hline \multirow{2}{*}{$\begin{array}{l}\text { Form } 1040 \\
\text { (Schedule F) item }\end{array}$} & \multicolumn{3}{|c|}{ Farms with $\leq 200$ cows } \\
\hline & MIG & Confinement & Difference \\
\hline Milk production (cwt/cow) & 144 & 188 & $43^{* * *}$ \\
\hline Milk sales $(\$ /$ cow $)$ & 2,752 & 3,443 & $691^{* * *}$ \\
\hline Crop sales ( $\$ /$ cow $)$ & 12 & 49 & $38^{* * *}$ \\
\hline Cattle sales $(\$ /$ cow $)$ & 240 & 206 & $-34^{* *}$ \\
\hline Income, other $(\$ /$ cow $)$ & 143 & 221 & $78^{* * *}$ \\
\hline Gross income $(\$ /$ cow $)$ & 3,147 & 3,920 & $774^{* * *}$ \\
\hline Car and truck $(\$ /$ cow $)$ & 7 & 8 & 1 \\
\hline Chemical expenses (\$/cow) & 22 & 96 & $73^{* * *}$ \\
\hline Conservation expenses $(\$ /$ cow $)$ & 2 & 3 & 1 \\
\hline Custom hire $(\$ /$ cow $)$ & 60 & 115 & $55^{* * *}$ \\
\hline Depreciation (\$/cow) & 362 & 347 & -15 \\
\hline Purchased feed expenses $(\$ /$ cow $)$ & 809 & 1,045 & $236^{* * *}$ \\
\hline Fertilizer expenses $(\$ /$ cow $)$ & 69 & 120 & $51^{* * *}$ \\
\hline Freight and trucking ( $\$ /$ cow $)$ & 82 & 136 & $54^{* * *}$ \\
\hline Fuel $(\$ /$ cow $)$ & 67 & 86 & $19^{* * *}$ \\
\hline Insurance, other than health $(\$ /$ cow $)$ & 31 & 54 & $23^{* * *}$ \\
\hline Interest $(\$ /$ cow $)$ & 120 & 132 & 11 \\
\hline Labor $(\$ /$ cow $)$ & 66 & 193 & $127^{* * *}$ \\
\hline Rent or lease $(\$ /$ cow $)$ & 168 & 174 & 6 \\
\hline Repairs and maintenance $(\$ / \mathrm{cow})$ & 175 & 270 & $95^{* * *}$ \\
\hline Seed $(\$ /$ cow $)$ & 67 & 79 & $12^{*}$ \\
\hline Supplies $(\$ /$ cow $)$ & 161 & 156 & -5 \\
\hline Taxes $(\$ /$ cow $)$ & 22 & 28 & $5^{*}$ \\
\hline Utilities $(\$ /$ cow $)$ & 78 & 87 & $10^{* * *}$ \\
\hline Veterinary, breeding, and medicine $(\$ /$ cow $)$ & 81 & 179 & $98^{* * *}$ \\
\hline Other expenses $(\$ /$ cow $)$ & 60 & 139 & $78^{* * *}$ \\
\hline Total expenses (\$/cow) & 2,511 & 3,456 & $946^{* * *}$ \\
\hline Net profit $(\$ /$ cow $)$ & 636 & 464 & $-172^{* * *}$ \\
\hline Milk production (metric; $\mathrm{kg} / \mathrm{cow}$ ) & 6,532 & 8,528 & $1,996^{* * *}$ \\
\hline
\end{tabular}

operators also sold more milk per cow than MIG operators; as a result, gross income per cow was $25 \%$ higher for the confinement operators than for MIG operators. Management-intensive grazing operators, however, had higher cattle sales per cow than confinement operators. Cows that are grazed have a longer productive life and the annual culling percentage for the herd is lower (Hanson et al., 1998). As a result, MIG operators sell more higher-value bred heifers and young stock, in contrast to confinement farmers who sell more lowervalue culled milk cows (White et al., 2002).

Higher output per cow in confinement operations came at a cost: total expenses per cow were higher for confinement operators. One obvious source of greater expense was purchased feed. More notable, however, were greater average costs of labor and veterinary, breeding, and medical expenses. Together with purchased feed, these 3 categories accounted for almost half the difference in total expenses between these 2 production systems.

Nearly all the confinement operations in this study used Holstein cows. Holsteins are a heavier breed than the Jerseys and cross breeds used by MIG operators.
Holsteins produce more milk and thus require more feed. Additionally, confined cows consume feed with a lower moisture content than grazed cows feeding on high-moisture pasture; thus, confined cows consume more feed (and are accordingly able to produce more milk).

Hired labor expenses per cow in confinement operations were roughly 3 times those in MIG operations (\$193/cow vs. $\$ 66 /$ cow). Dairy farmers, in general, have high labor requirements because of the need to milk twice a day as well as complete field work. One advantage of grazing is that farmers can reduce their field work. Management-intensive grazing operations also require less labor for barn cleaning, manure hauling, and feeding because the animals spend less time in the barn and more time feeding themselves. White et al. (2001) found that $85 \%$ of defecations and urinations occur in the pasture for the grazing herd, greatly reducing the amount of manure to be handled in the confinement system barn. This reduced labor requirement allows MIG operators to rely relatively more on unpaid family labor and less on paid hired labor than the confinement operations. 
Veterinary, breeding, and medicine costs per cow in MIG operations were less than half those in confinement operators ( $\$ 81 /$ cow vs. $\$ 179 /$ cow). A strong argument can be made that grazing is healthier for a cow than being confined. For example, Washburn et al. (2002) found that pastured dairy cows had lower incidence of mastitis than those dairy cows in the confinement system, and the confinement herd had more cows culled because of mastitis problems than the grazing herd.

Although confinement farmers had higher gross income per cow, they also had higher total expenses per cow. As a result, the confinement farmers had less profit per cow than MIG operators. These differences were larger than those found by Gillespie et al. (2009), who did not find differences in net profits.

Per Acre. Some farmers are able to grow their farm business and increase profits by acquiring more land. For other farmers, land is often the most limiting resource. Increasing farm size through land rental or purchase is problematic for dairy farmers. Crop farmers, by comparison, can rent or purchase land located long distances from their home operation. Crop equipment can be moved when highway traffic is at a minimum, and it is easier for crop farmers to haul harvested grain back to the farm than it is for livestock farmers to haul bulkier forage crops, such as hay and corn silage, back to the farm. For both confinement farmers and MIG operators, dairy manure is difficult to transport and can only be carried short distances to be spread on crop land. Management-intensive grazing operators face an additional problem in that cows can only walk so far to be milked. Grazing pastures must be contiguous to the main farm operation so that animals can be moved easily from barn to field twice a day. Consequently, dairy farmers are often limited to renting or buying land only from neighbors. All of these factors dealing with land constraints can lead dairy farmers to focus on maximizing profits per acre.

As one might expect given the high land requirements of MIG systems, confinement operators produced more milk per acre, sold more milk per acre, and had greater crop sales per acre (Table 5). At the same time, confinement operators incurred greater expenses per acre than MIG operators. Those greater expenses, combined with lower cattle sales, cancelled out advantages in milk production, milk sales, and crop sales, so that confinement operators earned less net profit per acre than MIG operators ( $\$ 183 /$ acre vs. $\$ 232 /$ acre).

\section{Farm Business Comparisons}

Farm Profit. The bottom line for dairy operation systems is how well they perform in generating a livable household income for the farm families that operate them. The relative performance of confinement and MIG operations on a whole-farm basis was similar to their relative performance per cow or per acre operated. Confinement operators produced more milk (19,727 cwt vs. 11,908 cwt) and had higher milk sales than MIG operators (Table 6). Confinement operators also had higher crop sales and income from other sources (e.g., cooperative distributions, agricultural program payments, crop insurance, custom hire, fuel tax credit). Confinement operators also had higher cattle sales. As a result, gross income was substantially higher for confinement operators than for MIG operators $(\$ 414,048$ vs. $\$ 260,298$ ). At the same time, confinement operators incurred much greater expenses than MIG operators. Some of these differences in expenses were attributable to crop production; for example, spending on fertilizers, fuel, seed, and chemicals. Because confinement operators had more crop equipment than MIG operators, their depreciation and maintenance costs were higher. Also, confinement operators produced more milk so their freight and trucking expenses associated with shipping milk were higher. Overall, then, confinement and MIG production systems generated the same average incomes for small dairy operators in the mid-Atlantic region. Further, those incomes are approximately equal to the annual real median household income in the United States as a whole (Semega, 2009).

Income Risk. Although both confinement and MIG systems generated roughly the same average levels of income, confinement operations were noticeably riskier (Table 7). As a result, the level of income met or exceeded 3 out of every 4 yr was approximately $40 \%$ higher under MIG systems than under confinement systems. Thus, MIG systems appear to be a more consistent, more reliable source of household income than confinement systems.

\section{Robustness of Results to Inclusion of Larger Operations and Exclusion of Organic Producers}

Almost all of the results obtained from analysis of the subsample of farmers with herds of $\leq 200$ cows were comparable to those of the full sample and the full sample excluding farmers selling organic milk (Table 8). The main differences were as follows. First, when organic producers were excluded from the analysis, gross income per hundred weight of milk (average price of milk received) no longer differed between MIG and confinement operations. Intensive grazing operations did, however, receive higher net profit per hundredweight of milk sold than confinement operators. Second, intensive grazing operations earned higher net profit per acre; that difference was not statistically significant in the full sample with or without organic producers, however. 
Table 5. Average annual values (per acre) between 2 types of dairy farms, management-intensive grazing (MIG) versus confinement, based on Form 1040 Schedule F, 1995 to $2009^{1}$

\begin{tabular}{|c|c|c|c|}
\hline \multirow{2}{*}{$\begin{array}{l}\text { Form } 1040 \\
\text { (Schedule F) item }\end{array}$} & \multicolumn{3}{|c|}{ Farms with $\leq 200$ cows } \\
\hline & MIG & Confinement & Difference \\
\hline Milk production (cwt/acre) & 47 & 68 & $21^{* * *}$ \\
\hline Milk sales (\$/acre) & 910 & 1,244 & $334^{* * *}$ \\
\hline Crop sales (\$/acre) & 3 & 13 & $9^{* * *}$ \\
\hline Cattle sales ( $\$$ /acre) & 79 & 70 & $-9^{*}$ \\
\hline Income, other (\$/acre) & 44 & 77 & $33^{* * *}$ \\
\hline Gross income (\$/acre) & 1,037 & 1,404 & $368^{* * *}$ \\
\hline Car and truck (\$/acre) & 3 & 2 & -1 \\
\hline Chemical expenses (\$/acre) & 6 & 32 & $26^{* * *}$ \\
\hline Conservation expenses (\$/acre) & 1 & 1 & 0 \\
\hline Custom hire (\$/acre) & 14 & 37 & $23^{* * *}$ \\
\hline Depreciation (\$/acre) & 116 & 127 & 12 \\
\hline Purchased feed expenses (\$/acre) & 267 & 387 & $119^{* * *}$ \\
\hline Fertilizer expenses (\$/acre) & 21 & 39 & $18^{* * *}$ \\
\hline Freight and trucking (\$/acre) & 26 & 47 & $21^{* * *}$ \\
\hline Fuel (\$/acre) & 23 & 31 & $8 * * *$ \\
\hline Insurance, other than health ( $\$$ /acre) & 13 & 17 & $4^{* *}$ \\
\hline Interest (\$/acre) & 41 & 45 & 4 \\
\hline Labor $(\$ /$ acre $)$ & 25 & 64 & $39 * * *$ \\
\hline Rent or lease $(\$ /$ acre $)$ & 49 & 58 & $9 *$ \\
\hline Repairs and maintenance (\$/acre) & 52 & 95 & $42^{* * *}$ \\
\hline Seed $(\$ /$ acre $)$ & 19 & 26 & $8 * * *$ \\
\hline Supplies (\$/acre) & 51 & 53 & 2 \\
\hline Taxes (\$/acre) & 9 & 9 & -1 \\
\hline Utilities (\$/acre) & 26 & 30 & $5^{* * *}$ \\
\hline Veterinary, breeding, and medicine ( $\$$ /acre) & 23 & 63 & $40^{* * *}$ \\
\hline Other expenses $(\$ /$ acre $)$ & 21 & 51 & $31^{* * *}$ \\
\hline Total expenses (\$/acre) & 805 & 1,221 & $416^{* * *}$ \\
\hline Net profit (\$/acre) & 232 & 183 & $-48^{* * *}$ \\
\hline Net profit (metric; $\$ /$ ha) & 573 & 452 & $-121^{* * *}$ \\
\hline
\end{tabular}

Third, when the full sample was used - with and without organic producers - confinement operations earned greater profit per farm. But there was no difference in profit; hence, the result was qualitatively the same as that obtained from the main analysis.

\section{General Discussion}

The foregoing comparisons indicate that MIG operations exhibited financial performance at least equal to that of confinement operations in the mid-Atlantic, at least for dairies of the relatively small sizes included in our sample. Management-intensive grazing operations produced less milk but incurred substantially lower costs. Management-intensive grazing operations were more profitable than confinement operations per hundredweight of milk produced and per cow and were no less profitable on a whole-farm basis (i.e., once size of operation was taken into account). Lower upfront expenditures made MIG operations less vulnerable to fluctuations in market conditions, weather, and other factors beyond the farmers' control. As a result, income was less risky in MIG operations than in confinement operations. These financial performance measures sug- gest that MIG systems may offer a way for small farms to compete in dairy production.

Management-intensive grazing systems may also enhance the sustainability of small dairy operations by allowing entry of greater numbers of young farmers. Management-intensive grazing operations require less equipment for crop production and smaller freestall areas in barns (because cows spend more of their time grazing in pasture). Lower upfront investment costs make them easier to finance and thus more accessible to new entrants lacking capital.

Management-intensive grazing systems are still relatively new, suggesting that there is likely considerable room for improvement. Innovations will likely be site specific, as researchers and farmers adjust grazing practices to suit soils and climate; on-farm learning by doing and experimentation are likely to play important roles in this process. Breeding of animals and pasturage better adapted to intensive grazing can also help increase productivity in MIG systems. As these innovations are developed, the advantages of MIG systems over confinement operations are likely to grow.

Agricultural commodity prices have been becoming more volatile. Increased demand due to economic 
Table 6. Average annual values (per farm) between 2 types of dairy farms, management-intensive grazing (MIG) versus confinement. based on Form 1040 Schedule F, 1995 to 2009

\begin{tabular}{|c|c|c|c|}
\hline \multirow{2}{*}{$\begin{array}{l}\text { Form } 1040 \\
\text { (Schedule F) item }\end{array}$} & \multicolumn{3}{|c|}{ Farms with $\leq 200$ cows } \\
\hline & MIG & Confinement & Difference \\
\hline Milk production (cwt/farm) & 11,908 & 19,727 & $7,819^{* * *}$ \\
\hline Milk sales $(\$ /$ farm $)$ & 227,789 & 362,088 & $134,299^{* * *}$ \\
\hline Crop sales (\$/farm) & 795 & 5,054 & $4,259^{* * *}$ \\
\hline Cattle sales ( $\$ /$ farm) & 19,208 & 20,797 & 1,589 \\
\hline Income, other ( $\$$ /farm) & 12,496 & 26,076 & $13,580^{* * *}$ \\
\hline Gross income (\$/farm) & 260,298 & 414,048 & $153,750^{* * *}$ \\
\hline Car and truck $(\$ /$ farm $)$ & 552 & 589 & 37 \\
\hline Chemical expenses ( $\$ /$ farm $)$ & 1,473 & 11,616 & $10,143^{* * *}$ \\
\hline Conservation expenses ( $\$ /$ farm) & 125 & 436 & 311 \\
\hline Custom hire $(\$ /$ farm $)$ & 4,573 & 12,060 & $7,487^{* * *}$ \\
\hline Depreciation $(\$ /$ farm $)$ & 28,628 & 35,224 & $6,596^{* * *}$ \\
\hline Purchased feed expenses $(\$ /$ farm $)$ & 67,938 & 107,649 & $39,711 * * *$ \\
\hline Fertilizer expenses $(\$ /$ farm $)$ & 5,384 & 11,863 & $6,479^{* * *}$ \\
\hline Freight and trucking ( $\$ /$ farm) & 7,627 & 14,738 & $7,111^{* * *}$ \\
\hline Fuel ( $\$ /$ farm) & 5,493 & 9,526 & $4,033^{* * *}$ \\
\hline Insurance, other than health ( $\$ /$ farm $)$ & 2,875 & 6,431 & $3,556^{* * *}$ \\
\hline Interest $(\$ /$ farm $)$ & 10,769 & 15,024 & $4,255^{* * *}$ \\
\hline Labor $(\$ /$ farm $)$ & 5,529 & 23,977 & $18,448^{* * *}$ \\
\hline Rent or lease $(\$ /$ farm $)$ & 13,562 & 17,424 & $3,862^{* *}$ \\
\hline Repairs and maintenance ( $\$$ /farm) & 14,363 & 28,078 & $13,715^{* * *}$ \\
\hline Seed $(\$ /$ farm $)$ & 5,494 & 8,183 & $2,689 * * *$ \\
\hline Supplies (\$/farm) & 12,779 & 16,071 & $3,292^{* * *}$ \\
\hline Taxes $(\$ /$ farm $)$ & 2,015 & 3,003 & $988^{* * *}$ \\
\hline Utilities $(\$ /$ farm $)$ & 6,216 & 9,230 & $3,014^{* * *}$ \\
\hline Veterinary, breeding, and medicine $(\$ /$ farm $)$ & 6,655 & 18,972 & $12,317^{* * *}$ \\
\hline Other expenses $(\$ /$ farm $)$ & 4,907 & 14,748 & $9,841^{* * *}$ \\
\hline Total expenses $(\$ /$ farm $)$ & 206,914 & 366,221 & $159,307^{* * *}$ \\
\hline Net profit $(\$ /$ farm $)$ & 53,383 & 47,826 & $-5,557$ \\
\hline Milk production (metric; $\mathrm{kg} /$ farm) & 540,138 & 894,802 & $354,664^{* * *}$ \\
\hline
\end{tabular}

growth in developing countries and to the growth of biofuel uses has made commodity markets more susceptible to fluctuations in production. Decreased reliance on purchased feed and lower upfront expenditures make MIG systems less vulnerable to volatility in commodity prices. Lower risk is thus likely to become an increasingly important advantage of MIG systems.

Milk produced in MIG operations has several attributes that command higher prices today and seem likely to continue to do so in the future. As noted above, some MIG farmers have become organically certified. The transition to organic production is not as difficult when beginning from a MIG base. Some consumers are willing to pay more for livestock products from operations that provide greater animal welfare. Thus, MIG operations can be seen as a more natural, cow-friendly form of dairying. Lower veterinary expenses per cow, longer milking lifespans (or fewer frequencies of culling), and higher values of cow for sale (e.g., higher quality bred heifers) all indicate that cows are healthier in MIG systems than in confinement systems. It may thus be possible to market milk from MIG producers as an enhanced animal welfare product with a premium price.

In many areas, environmental regulations are likely to target agricultural operations that have heretofore been largely exempt from them. For example, new water quality regulations affecting the Chesapeake Bay watershed, where the dairy operations in this study are located, are likely to require reductions in runoff of nitrogen and phosphorus from smaller agricultural operations similar to those that the current effluent discharge regulations impose on large confined animal feeding operations. Management-intensive grazing operations have lower nutrient runoff than confinement operations

Table 7. Riskiness of income: management-intensive grazing versus confinement operations, 1995 to 2009

\begin{tabular}{lccc}
\hline Farm type & $\begin{array}{c}\text { Average annual } \\
\text { profit }(\$)\end{array}$ & SD & $\begin{array}{c}75 \% \text { lower } \\
\text { confidence limit }^{1}\end{array}$ \\
\hline Management-intensive grazing & 54,901 & 32,055 & 36,405 \\
Confinement & 48,137 & 38,236 & 26,075 \\
\hline
\end{tabular}

${ }^{1}$ Indicates the profit attained in 3 out of every 4 yr. 
Table 8. Comparison of milk production, gross income, total expenses, and net profit for different farm sizes and units: management-intensive grazing (MIG) versus confinement operations, 1995 to 2009

\begin{tabular}{|c|c|c|c|c|c|c|c|c|c|}
\hline \multirow{2}{*}{$\begin{array}{l}\text { Farm } 1040 \\
\text { (Schedule F) item }\end{array}$} & \multicolumn{3}{|c|}{ Farms with $\leq 200$ cows } & \multicolumn{3}{|c|}{ Full sample } & \multicolumn{3}{|c|}{ Full sample, no organic } \\
\hline & MIG & Confinement & Difference & MIG & Confinement & Difference & MIG & Confinement & Difference \\
\hline \multicolumn{10}{|l|}{ Per hundredweight of milk } \\
\hline Milk production (cwt) & - & - & - & - & - & - & - & - & - \\
\hline Gross income (\$/cwt) & 22.55 & 21.03 & $-1.52^{* * *}$ & 19.01 & 17.60 & $-1.42^{* * *}$ & 17.88 & 17.53 & -0.36 \\
\hline Total expenses (\$/cwt) & 17.8 & 18.58 & $0.78^{* *}$ & 14.95 & 15.54 & $0.59^{* *}$ & 14.35 & 15.50 & $1.15^{* * *}$ \\
\hline Net profit $(\$ /$ cwt $)$ & 4.75 & 2.45 & $-2.30^{* * *}$ & 4.06 & 2.06 & $-2.00^{* * *}$ & 3.53 & 2.03 & $-1.51^{* * *}$ \\
\hline \multicolumn{10}{|l|}{ Per cow } \\
\hline Milk production (cwt/cow) & 144 & 188 & $43^{* * *}$ & 144 & 190 & $46^{* * *}$ & 149 & 190 & $41^{* * *}$ \\
\hline Gross income $(\$ /$ cow $)$ & 3,147 & 3,920 & $774^{* * *}$ & 2,585 & 3,320 & $735 * * *$ & 2,599 & 3,320 & $721^{* * *}$ \\
\hline Total expenses (\$/cow) & 2,511 & 3,456 & $946^{* * *}$ & 2,054 & 2,925 & $871^{* * *}$ & 2,096 & 2,927 & $830 * * *$ \\
\hline Net profit $(\$ /$ cow $)$ & 636 & 464 & $-172^{* * *}$ & 532 & 395 & $-137 * * *$ & 502 & 393 & $-110^{* * *}$ \\
\hline \multicolumn{10}{|l|}{ Per acre } \\
\hline Milk production (cwt/acre) & 47 & 68 & $21^{* * *}$ & 47 & 72 & $25^{* * *}$ & 49 & 72 & $24^{* * *}$ \\
\hline Gross income (\$/acre) & 1,037 & 1,404 & $368^{* * *}$ & 860 & 1,270 & $411^{* * *}$ & 851 & 1,270 & $419^{* * *}$ \\
\hline Total expenses ( $\$$ /acre) & 805 & 1,221 & $416^{* * *}$ & 665 & 1,106 & $441^{* * *}$ & 673 & 1,107 & $434^{* * *}$ \\
\hline Net profit $(\$ /$ acre $)$ & 232 & 183 & $-48^{* * *}$ & 195 & 164 & -31 & 179 & 164 & -15 \\
\hline \multicolumn{10}{|l|}{ Per farm } \\
\hline Milk production (cwt/farm) & 11,908 & 19,727 & $7,819^{* * *}$ & 11,545 & 22,952 & $11,407^{* * *}$ & 12,202 & 22,992 & $10,790^{* * *}$ \\
\hline Gross income $(\$ /$ farm $)$ & 260,298 & 414,048 & $153,750^{* * *}$ & 207,118 & 411.046 & $203,928^{* * *}$ & 212,600 & 411,294 & $198,694^{* * *}$ \\
\hline Total expenses (\$/farm) & 206,914 & 366,221 & $159,307 * * *$ & 163,308 & 361,580 & $198,272^{* * *}$ & 171,348 & 362,023 & $190,675^{* * *}$ \\
\hline Net profit $(\$ /$ farm $)$ & 53,383 & 47,826 & $-5,557$ & 43,811 & 49,467 & 5,656 & 41,251 & 49,270 & 8,019 \\
\hline
\end{tabular}

D. *****Significant difference between MIG and confinement dairies at the 5 and $1 \%$ levels, respectively. 
and will thus likely incur lower compliance costs if and when new, stricter regulations are implemented.

Land requirements likely impose the principal limitation on the size of intensive grazing operations. In the mid-Atlantic, for instance, grazing operations need 1.5 to 2.0 acres of pasture for every dairy cow/calf equivalent to provide sufficient grass to support a dairy operation. Pasture land for MIG operators must be contiguous to the milking parlor and located no farther than a cow can walk to and from twice a day. That requirement limits the maximum size of an intensive grazing operation. A lack of contiguous pasture land near their farms may create an absolute barrier to expanding the size of grazing operations to levels below that maximum as well. And in areas where land prices are high, as they are in much of the mid-Atlantic, expansion of grazing operations beyond the 200-cow limit in this study may not be economically justifiable.

\section{CONCLUSIONS}

This paper examines the comparative characteristics and relative performances of small $(<200$ cow $)$ MIG and confinement dairy operators over a 15 -yr period. The MIG operators were more profitable on per hundredweight, per cow, and per acre bases and were no less profitable on a whole-farm basis. Although confinement operators had higher gross income than MIG operators, their expenses tended to be greater than or equal to those of MIG operators. Profits of MIG operations were less variable as well, so that MIG operators faced less income risk. Increased reliance on grazing was associated with improved animal health, as reflected in lower veterinary, breeding, and medicine costs per cow and greater income from the sale of animals. The MIG operators were less labor intensive as well. Lower capital and labor requirements, lower variable expenses, and lower income risk make intensive grazing systems attractive for new entrants to the dairy business. Stricter environmental regulations may increase their attractiveness as well. Land requirements likely impose the principal limitation on the size of intensive grazing operations.

\section{REFERENCES}

Bishop, P. L., W. D. Hively, J. R. Stedinger, M. R. Rafferty, J. L. Lojpersberger, and J. A. Bloomfield. 2005. Multivariate analysis of paired watershed data to evaluate agricultural best management practice effects on stream water phosphorus. J. Environ. Qual. 34:1087-1101.

Dartt, B. A., J. W. Lloyd, B. R. Radke, J. R. Black, and J. B. Kaneene. 1999. A comparison of profitability and economic efficiencies between management-intensive grazing and conventionally managed dairies in Michigan. J. Dairy Sci. 82:2412-2420.

Digiacomo, G., C. Iremonger, L. Kemp, C. van Schaik, and H. Murray. 2001. Sustainable farming systems: Demonstrating environmental and economic performance. Minnesota Institute for Sustainable Agriculture (MISA), University of Minnesota, St. Paul. Accessed Jan. 17, 2011. http://www.misa.umn.edu/prod/groups/cfans/@ pub/@cfans/@misa/documents/asset/cfans_asset_287080.pdf.

Fontaneli, R. S., L. E. Sollenberger, R. C. Littell, and C. R. Staples. 2005. Performance of lactating dairy cows managed on pasturebased or in freestall barn-feeding systems. J. Dairy Sci. 88:12641276 .

Gillespie, J., R. Nehring, C. Hallahan, and C. Sandretto. 2009. Pasture-based dairy systems: Who are the producers and are their operations more profitable than conventional dairies? J. Agric. Res. Econ. 34:412-427.

Gloy, B. A., J. Hyde, and E. LaDue. 2002. Dairy farm management and long-term farm financial performance. Agric. Res. Econ. Rev. 31:233-247.

Guo, L. B., and R. M. Gifford. 2002. Soil carbon stocks and land use change: A meta-analysis. Glob. Change Biol. 8:345-360.

Hanson, G. D., L. C. Cunningham, M. J. Morehart, and R. L. Parsons. 1998. Profitability of moderate intensive grazing of dairy cows in the Northeast. J. Dairy Sci. 81:821-829.

Kriegl, T. 2005. Pastures of plenty: Financial performance of Wisconsin grazing dairy farms. Center for Integrated Agricultural Systems. University of Wisconsin, Madison. Accessed Aug. 29, 2011. http://www.cias.wisc.edu/crops-and-livestock/pastures-of-plentyfinancial-performance-of-wisconsin-grazing-dairy-farms/.

MacDonald, J. M., E. J. O'Donoghue, W. E. McBride, R. F. Nehring, C. L. Sandretto, and R. Mosheim. 2007. Profits, costs, and the changing structure of dairy farming. Economic Research Report Number 47. Economic Research Services, USDA, Washington, DC.

Mosheim, R., and C. A. K. Lovell. 2009. Scale economies and inefficiency of U.S. dairy farms. Am. J. Agric. Econ. 91:777-794.

Musser, W. N., J. Ohannesian, and F. J. Benson. 1981. A safety first model of risk management for use in extension programs. North Central J. Agric. Econ. 3:41-46.

Nehring, R., J. Gillespie, C. Sandretto, and C. Hallahan. 2009. Small U.S. dairy farms: Can they compete? Agric. Econ. 40:817-825.

Renfrew, R. B., and C. A. Ribic. 2001. Grassland birds associated with agricultural riparian practices in southwestern Wisconsin. J. Range Manage. 54:546-552.

Semega, J. 2009. Median household income for states: 2007 and 2008. American Community Surveys. ACSBR/08-2, US Census Bureau, Washington, DC. Accessed Sep. 26, 2011. https://www.census. gov/prod/2009pubs/acsbr08-2.pdf.

Taylor, J., and J. Foltz. 2006. Grazing in the dairy state: Pasture use in the Wisconsin dairy industry, 1993-2003. Center for Integrated Agricultural Systems and Program on Agricultural Technology Studies, University of Wisconsin, Madison. Accessed Dec. 7, 2012. http://www.pats. wisc.edu/pubs/pdf.ashx?pubsID $=62$.

Tozer, P. R., F. Bargo, and L. D. Muller. 2003. Economic analyses of feeding systems combining pasture and total mixed ration. J. Dairy Sci. 86:808-818.

Washburn, S. P., S. L. White, J. T. Green Jr., and G. A. Benson. 2002 Reproduction, mastitis, and body condition of seasonally calved Holstein and Jersey cows in confinement or pasture systems. J. Dairy Sci. 85:105-111.

White, S. L., G. A. Benson, S. P. Washburn, and J. T. Green Jr. 2002. Milk production and economic measures in confinement or pasture systems using seasonally calved Holstein and Jersey cows. J. Dairy Sci. 85:95-104

White, S. L., R. E. Sheffield, S. P. Washburn, L. D. King, and J. T. Green Jr.. 2001. Spatial and time distribution of dairy cattle manure in an intensive pasture system. J. Environ. Qual. 30:2180-2187.

Winsten, J. R., C. D. Kerchner, A. Richardson, A. Lichau, and J. M. Hyman. 2010. Trends in the Northeast dairy industry: Large-scale modern confinement feeding and management-intensive grazing. J. Dairy Sci. 93:1759-1769.

Winsten, J. R., R. L. Parsons, and G. D. Hanson. 2000. Differentiated dairy grazing intensity in the Northeast. J. Dairy Sci. 83:836-842.

Winsten, J. R., and J. R. Stokes. 2004. The efficacy of controlling phosphorus loading: the case of management-intensive grazing. Agric. Syst. 79:283-303. 